 \\ z Filologii Polskiej \\ i Słowiańskiej
}

\section{Z problematyki polskich i słoweńskich analityzmów kauzatywnych z parafrazą przymiotnikową}

Tematem artykułu są analityczne eksplikacje jednostek języka zawierające w swej budowie semantycznej predykat kauzatywny, których znaczenie można wydobyć przy pomocy parafrazy zawierającej przymiotnik. Obiektem dociekań są zatem różne konstrukcje analityczne, nie tylko werbo-nominalne, będące już przedmiotem oddzielnych studiów $\mathrm{w}$ językoznawstwie polonistycznym (Żmigrodzki, 2000) i slawistycznym (Mindak, 1983). Zdecydowano się na pokazania różnorodnych sposobów językowej manifestacji kauzacji cechy przez wykładniki analityczne. Artykuł nie pretenduje zatem do roli głosu w dyskusji nad definiowaniem i zakreślaniem granic zbiorów analityzmów werbo-nominalnych. Zamiarem autora jest pokazanie sposobów ujawniania treści kauzatywnych w strukturach analitycznych. Szczególny nacisk zostanie położony na ukazanie kształtu i funkcji czasowników operatorowych wewnątrz konstrukcji analitycznych.

Badania, które posłużyły za podstawę niniejszego artykułu, oparto przede wszystkim na metodologii składni semantycznej, w myśl której centralnym

This is an Open Access article distributed under the terms of the Creative Commons Attribution 3.0 PL License (creativecommons.org/licenses/by/3.0/pl/), which permits redistribution, commercial and non-commercial, provided that the article is properly cited. () The Author(s) 2015. 
obiektem badań jest zdanie i fundująca je struktura predykatowo-argumentowa. Zastosowano też elementy metody komponencjalnej, postulat rozkładania znaczeń na komponenty możliwie proste i ujawnianie w ten sposób różnic pomiędzy jednostkami języka. W badaniach języka lingwiści nurtu składni semantycznej postulują rozdzielenie płaszczyzny powierzchniowej, formalnej i płaszczyzny głębszej, semantycznej. Takie ujęcie jest zastosowane również tutaj. Analiza rozpatrywanego materiału pozwala także na pokazanie sposobów komponowania, komplikowania treści bazowego predykatu kauzatywnego poprzez dodatkowe elementy. Za Małgorzatą Korytkowską (Korytkowska, 1992; Korytkowska \& Maldżieva, 1999) zdecydowano się na wykorzystanie terminu predykator i zastosowanie go na poziomie pośrednim między płaszczyzną semantyczną, logiczną, na której znajdują się podstawowe struktury predykatowo-argumentowe, a poziomem powierzchniowym, na którym owe treści formalizowane są w postaci językowej. Termin ten znalazł zastosowanie w monografii Polskie i słoweńskie predykatory kauzatywne z parafraza przymiotnikowa (Zatorska, 2013). Podstawowym narzędziem badawczym jest parafraza, czyli wskazanie takiego konstruktu, który jest dopuszczany przez dany system językowy, a zarazem semantycznie najbliższy wyjaśnianemu wyrażeniu.

W wybranych predykatorach zaobserwowano dwudzielną budowę, która wpisuje analizowane przykłady w tradycję badań nad zwrotami werbo-nominalnymi, analityzmami, AWN (Żmigrodzki, 2000), predykatorami analitycznymi (Korytkowska \& Maldżieva, 1999) i peryfrastycznymi konstrukacjami predykatywnymi (Mindak, 1983). W prezentowanych predykatorach analitycznych treść posiadania danej cechy $Y$ - bycia $Y$, gdzie $Y$ oznacza daną cechę, wyeksplikowana jest w postaci nominalnej np. pol. intensywność - intensywny, jędrność - jędrny, młodość - młody, suchość - suchy; słoweń. intenzivnost - intenziven, jedrnatost - jedrnat, mladost - mlad, suhost - suh. Jako znominalizowane wykładniki predykatu służą w obu językach rzeczowniki powiązane relacją słowotwórczą z korespondującym $\mathrm{z}$ nimi przymiotnikami. $\mathrm{W}$ tej funkcji przeważają rzeczowniki tworzone formantem pol. -ość i słoweń. -ost, np. pol. efektywność, intensywność, jędrność, młodość, skuteczność, suchość oraz słoweń. efektnost, intenzivnost, jedrnatost, mladost, neumnost, suhost, učinkovitost. Ponadto obserwujemy derywaty tworzone przez formanty pol. -ota - glupota, prostota; - -two - męstwo; słoweń. -oba - mehkoba, svetloba, tesnoba; -ota - toplota, -tvo - moštvo. Drugim członem omawianych konstrukcji jest czasownik operatorowy, w którego znaczenie wpisany jest predykat kauzatywny powierzchniowo sygnalizowany przez parę czasowników powodować / spowodować. Polskie czasowniki 
powodować - spowodować, a także czynić - uczynić, np. Wytwórca nadał tkaninie miękkość - Wytwórca spowodował, że tkanina jest miękka / spowodował, że jest miękka oraz słoweńskie delati, narediti służą jako obligatoryjne elementy tworzonych parafraz. W języku słoweńskim podobne funkcje może także pełnić czasownik povzročiti - povzročati, wykazuje on jednak pewne ograniczenia w łączliwości, dlatego za podstawowe składniki parafrazy przyjęto delati i narediti, por. Izdelku so dodali mehkobo - Izdelek so naredili bolj mehek. Frazy z czasownikiem uczynić - czynić mają wobec badanego zbioru predykatorów charakter podstawowy i obok czasowników spowodować - powodować mogą być traktowane jako służące do parafrazowania i definiowania jednostek zbioru. Dla analizowanego zbioru funkcję werbalizatorów - czasowników operatorowych wewnątrz danego związku wyrazowego - pełnią zróżnicowane znaczeniowo czasowniki, modyfikowane przez różne nadwyżki semantyczne wobec podstawowego predykatu kauzatywnego, por. pol. nadać, narzucić, obdarzyć, przedłużyć, przywrócić, zmniejszyć, zwielokrotnić - nadać smukłość, narzucić ubóstwo, obdarzyć pięknem, przedłużyć młodość, przywrócić jędrność, zmniejszyć suchość, zwielokrotnić intensywność oraz słoweń. dati, dodajati, podariti, podaljšati, povečati, vrniti, zmanjšati - dati svetlobo, dodajati mehkobo, podariti mladost, vrniti jedrnatost, povečati sipkost, zmanjšati gostoto etc.

Dzięki budowie tworzonej przez wykładniki powodowania i cechy w postaci oddzielnych elementów językowych - realizujących kategorie werbalne i nominalne - analityczne konstrukcje kauzatywne często wydatniej niż bliskoznaczne wobec nich predykatory werbalne eksponują zróżnicowanie oraz komplikację semantyczną w czasownikowym wyrażaniu owego powodowania. Wyłania się tutaj cały zespół zagadnień związanych z relacją między czasownikowym odpowiednikiem analityzmu, por. pol. ujędrnić - ujędrniać vs. nadać jędrność nadawać jędrność, np. X ujędrnit $Y-X$ ujędrnia $Y-X$ nadał $Y$-owi jędrność $X$ nadaje $Y$-owi jędrność. Zarówno podane czasowniki, jak i analityzmy, można sparafrazować przez: X spowodowat / powoduje, że Y jest / zaczyna być jędrne. Oba warianty - zarówno werbalny, jak i analityczny - podanych predykatorów możemy zilustrować przez ekwiwalent w postaci frazy: X uczynił / czyni Y jędrnym. Wybór modelu składni semantycznej, w myśl której podstawą klasyfikacji badanych jednostek języka w strukturach zdaniowych jest traktowanie ich jako wykładników podstawowych struktur logicznych, predykatowo-argumentowych, pozwala uchwycić różnicę między odmiennymi systemami językowymi w zakresie strukturyzacji treści mającej u swych podstaw tę samą strukturę wyjściową (Kiklewicz \& Korytkowska, 2010; Zatorska, 2013). 
Zaobserwowane zjawiska są pochodną analizy zbioru liczącego po 50 predykatorów dla języka polskiego i słoweńskiego. W artykule wykorzystano fakty $\mathrm{z}$ dwu różnych - choć pokrewnych - systemów językowych z kręgu języków słowiańskich. Jakkolwiek artykuł przedstawia elementy analizy konfrontatywnej, to jednak większość obserwacji ma charakter ilustrujący zjawiska $\mathrm{z}$ danego systemu językowego. Przytoczone zdania zaczerpnięto przede wszystkim z korpusów języka - dla języka polskiego z Narodowego Korpusu Języka Polskiego, dalej NKJP, dla zdań przekształconych NKJPp, a dla języka słoweńskiego z korpusu Nova Beseda, dalej NB lub analogicznie NBp.

Różnice w możliwościach eksplikacji treści predykatu kauzatywnego w predykatorach parafrazowanych przez przymiotnik między językami polskim i słoweńskim były już obserwowane w badanich lingwistycznych (Zatorska, 2010, 2012, 2013). Materiał wykazuje rozmaite możliwości systemów językowych w zakresie wyrażania treści bliskoznacznej. Jednostce werbalnej w jednym języku odpowiada realizujący podobną strukturę znaczeniową związek wyrazowy. Sytuację taką ilustruje słoweń. zresniti (Zatorska, 2013, s. 103), np. Ta dogodek ga je zresnil, gdy w języku polskim frazę tę możemy oddać przy pomocy zdania z wykładnikiem analitycznym por. uczynić madrym, obdarzyć mądrościa - To wydarzenie / doświadczenie uczyniło go mądrym / obdarzyło go mądrościa. Podobnie zdaniom ze słoweńskimi czasownikami obnoreti, zanoriti, np. Obnorela ga je. Zanorila ga je. (który można przetłumaczyć na język polski przy pomocy parafrazujących fraz: Uczyniła go szalonym / Spowodowała, że jest / zaczął być szalony) odpowiadają w polszczyźnie translacje z konstrukcjami analitycznym, np. Doprowadziła go do szaleństwa. Odwrotna sytuacja występuje przy eksplikacji znaczenie czynienia płytszym / bardziej płytkim, który w języku polskim możemy wyrazić przez czasowniki spłycić splycać, np. Budowlańcy splycili sadzawke, podczas gdy w języku słoweńskim znaczenie bliskoznaczne może być wyrażony tylko przy pomocy konstrukcji analitycznych, np. povečati plitkost - Povečali so plitkost vode.

Jednym z kluczowych zagadnień przy opracowywaniu konstrukcji analitycznych jest dobór werbalizatorów. Za podstawowe czasowniki obsługujące analityczne konstrukcje kauzatywne badacze uznają verba budzić - wzbudzić wzbudzać (Żmigrodzki, 2000, s. 196), por. słoweń. buditi - vzbuditi-vzbujati. Są one nielicznie reprezentowane w analizowanym materiale i ograniczają się przede wszystkim do określeń stanów psychicznych człowieka, np. pol. Zachowanie ludzi budzi w nim wesołość - To, w jaki sposób zachowuja się ludzie, powoduje (to), że on zaczyna być wesoły. W parafrazie zdania wyjściowego 
odnajdujemy przymiotnik wesoły $\mathrm{w}$ funkcji predykatywnej być wesołym, w znaczeniu aktualnym. Badane konstrukcje wykazują znaczną kondensację semantyczną, zwłaszcza przy wyrażaniu ludzkich emocji, odczuć. Odnotowane w nich przymiotniki, czasowniki bądź analityzmy nie tyle korespondują $\mathrm{z}$ atrybucją wobec danego przedmiotu czy stanu rzeczy, ile określają odbiór owego stanu rzeczy. Słoweńskie: Odprti prostori so vzbujali tesnobo. NBp zawiera konstrukcję vzbujati tesnobo, ale z kontekstu wynika, że 'Otwarte przestrzenie raczej wzbudzity (u kogoś) wrażenie ciasnoty' niż 'wzbudzity ciasnotę. Za gatunkowy kauzatywny czasownik operatorowy badacze uznają także verbum wywoływać (Żmigrodzki, 2000, s. 196), por. wywołać - wywoływać - Napowietrzanie wywołuje puszystość lodów NKJPp.

Wśród czasowników operatorowych odpowiadających relacji przyczynowej możemy wyodrębnić kilka grup. Jedna $\mathrm{z}$ nich gromadzi verba związane $\mathrm{z}$ transferem, np. dać - dawać - Pieniądze czasem dają niezależność NKJPp; Przejrzysta koronkowa suknia dała smukłość jej postaci NKJPp; dodać - dodawać - Szerokie otwarte przejście dodało przestronności tej części mieszkania CZK. Pigment dodaje cerze świetlistości TS; nadać - nadawać - Wytwórcy nadaja filcowi miękkość NKJPp; Leczenie nadaje stawom odpowiednia giętkość NKJPp; Stylista nadal fryzurze klientki puszystość; Leczenie nadało sprężystość komórkom ciała NKJPp; obdarzyć - obdarzać - Bóg obdarzyt ja płodnościa NKJPp; przydać - przydawać - Dzień przydat niebu błękitu NKJPp; odebrać - odbierać - To zdarzenie odebrało mu spokój. Nocne telefony odbieraja jej spokój; ofiarować - Środowisko korporacyjne ofiarowało jej łatwość awansu NKJPp; wnieść - wnosić - Jako Papież wnióst na Stolice Piotrowa ogromny dynamizm i otwartość NKJPp; Ktoś przecież wnióst w nasze dzisiejsze życie zapobiegliwość, rzutkość, pracowitość NKJPp. Druga grupa powiązana jest z czasownikami ruchu, por. doprowadzić - doprowadzać Zastosowanie klimatyzacji doprowadziło do nadmiernej suchości powietrza w pomieszczeniach NKJPp; prowadzić - Hedonistyczna postawa dzisiejszego świata prowadzi do niemoralności NKJPp; przywieść - przywodzić - Postępowanie brata przywiodło ja do egoizmu.; wprowadzić - wprowadzać - Firma wprowadziła elastyczność wydatków NKJPp; Zastosowanie jasnych, spokojnych barw wprowadza do wnętrza naturalność. Analizowane konteksty wskazują, że prowadzić - doprowadzić - doprowadzać można przede wszystkim do czegoś niepożądanego. Za nieakceptowalne uznajemy frazy ${ }^{*}$ Doprowadził ja do piękna / dobroci / szlachetności. Materiał słoweński dokumentuje czasowniki transferu jako werbalizatory, por. povrniti - Terapija ji je povrnila mladost; 
nest $i$ - prinesti - prinašati - Projekt jim je prinesel stabilnost NBp; Nenadzorovana hitrost prinaša nevarnost NBp; Poezija prinaša nežnost v naše življenje; vzeti-odvzeti - Vojna mu je odvzela mladost, jak również w tej samej roli czasowniki ruchu, np. privesti - Ta dogodek ga je privedel $\boldsymbol{k}$ modrosti.

Wątek przenoszenia znaczeń czasowników czynności fizycznych ku stanom mentalnym czy zdarzeniom informacyjnym był już przedmiotem dociekań lingwistycznych (Grzegorczykowa, 2003). Czasownik powodować był początkowo bliski verbum kierować, np. powodować koniem, a czasownik wywoływać o znaczeniu 'podawać do wiadmości' należał do verbów informacyjnych. Również czasowniki prowadzić do, doprowadzać do, doprowadzić do funkcję kauzalną uzyskały dopiero w XX wieku (Grzegorczykowa, 2003, s. 103).

Współcześnie analityzmy polskie i słoweńskie dokumentują poprzez obecność werbalizatorów proces specjalizacji wybranych czasowników w sygnalizowaniu sekwencji przyczynowej. Operatory kauzacji wybierane są spośród czasowników mających swoje autonomiczne znaczenia. Sposobem na zilustrowanie repertuaru werbalizatorów w konstrukcjach kauzatywnych może być ich uporządkowanie według kategorii semantycznych spełnianych przez podane analityzmy. Wspólną dla wszystkich badanych jednostek predykatywnych jest kategoria kauzatywna. Zestaw wybranych kategorii semantycznych, według których sklasyfikowano badane konstrukcje analityczne, sporządzono na wzór wcześniejszych publikacji (Zatorska, 2013, ss. 274-281; Żmigrodzki, 2000). Kategoria inchoatywności jest sygnalizowana w badanych przykładach przez inchoatywny charakter czasowników operatorowych, np. pol. rodzić - Ogólna sytuacja rodzi ociężałość i apatię TS; zbudzić - Zachowanie Piotra zbudziło $w$ nim wesołość; słoweń. zbuditi - Petrovo dejanje je zbudilo njegovo veselje. Znaczenie terminatywne sygnalizujące anulowanie pewnej cechy może być wprowadzane przez czasowniki operatorowe nazywające transfer negatywny, pozbawienie czegoś, $\mathrm{w}$ tym przypadku spowodowanie utraty danej cechy, np. pol. odbierać - odebrać - Aranżacje odbierają rzeczom banalność NKJPp; pozbawić Ciemność pozbawiła go wesołości. Terapia pozbawiła skórę pacjentki jędrności; słoweń. odstraniti - Odstranili so suhost; odvzeti - Tema mu je odvzela veselje. Terapija ji je odvzela jedrnatost kože. Policisti so ji odvzeli prostost NBp.

Kategoria restauratywności związana jest z przywróceniem poprzedniego stanu. Kauzatywa analityczne w obu językach również ją egzemplifikują przy użyciu urozmaiconego wyboru werbalizatorów, np. pol. odbudowywać - Pielegnacja odbudowuje gęstość skóry TSp; przywrócić - przywracać - Przeor przywrócił klasztor do świetności NKJPp; Stosowanie mleczka kosmetycznego przywraca skórze elastyczność NKJPp; Artysta przywraca ludziom 
godność NKJPp; słoweń. povrniti - Človeku bodo povrnili dostojanstvo NBp; $Z$ novostmi so sistemu povrnili funkcionalnost $\mathrm{NBp} ; Z$ operacijo so $j$ i povrnili dekliškost; vračati - Kozmetičarka z masažo vrača stranki jedrnatost kože.

Czasowniki operatorowe są również wykładnikami kategorii stopnia, kategorii intensywności. Warto zaznaczyć, że w wyrażaniu modyfikacji intensywności cechy w obrębie konstrukcji analitycznych uczestniczą czasowniki kauzatywne. W badanym materiale obserwujemy dobór werbalizatorów pociągający za sobą zwiększanie lub zmniejszanie intensywności kauzowanej cechy (Zatorska, 2012, 2013). Charakterystyczne jest funkcjonowanie czasowników określających zmiany wymiarów jako werbalizatorów. O zwiększeniu intensywności cechy informują pol. powiększyć - powiększać oraz zwiększyć - zwiększać - Odwilżzwiększa gęstość pokrywy śnieżnej NKJPp; Stosowanie leków hormonalnych zwiększa lepkość krwi u pacjentki NKJPp oraz słoweńskie večati - povečati - povečevati, zvečati Lani so $v$ bavarskih Alpah drastično povečali gostoto anten NBp. Zmniejszenie intensywności cechy jest eksplikowane przy pomocy pol. pomniejszyć - pomniejszać - Narzucenie firmie struktury pomniejsza ogólna efektywność NKJPp; zmniejszyć-zmniejszać - Kuracja jodowa zmniejsza lepkość krwi NKJPp; Zmiany fizyczne zmniejszaja przepuszczalność gruntu; słoweń. manjšati - zmanjšati zmanjševati - Gozdarje so zmanjšali nevarnost naravnih požarov NBp; Terapija zmanjša bolnikovo gostoto kosti NBp. Skomplikowane semantycznie czasowniki zmiany wymiaru jako operatory łączą się z komplikacją znaczeniową wynikającą z polisemii przymiotników leżących u podstawy tworzonych konstrukcji analitycznych, por. zmanjšati gostoto - Vodstvo univerze je zmanjšalo gostoto izipitov NBp. Oprócz wymienionych czasowników odnoszących się do podstawowych określeń wymiaru jak duży - większy oraz mały - mniejszy w funkcji werbalizatorów przy sygnalizowaniu gradacji cechy odnajdujemy również czasowniki związane ze zmianą wysokości np. podwyższyć - podwyższać - Specjalne preparaty podwyższaja wytrzymałość roślin na mróz NKJPp; obniżyć - obniżać - Postawy roszczeniowe obniżaja efektywność całego systemu społecznego NKJPp; Podawanie leków obniża krzepliwość krwi u pacjenta NKJPp; Przemoc obniża psychiczna odporność NKJPp, a także pol. podnieść - podnosić - Nowoczesne rozwiązania podnoszą bezpieczeństwo jazdy TSp; Amfetamina podnosi sprawność organizmu, ale powoduje uzależnienie NKJPp. Znaczenie zwiększania głębokości służy również jako podstawa werbalizatorów odpowiadających w badanych konstrukcjach za wyrażanie powodowania danej cechy jako bardziej intensywnej, por. pol.pogłębić - pogłębiać - Ogólna sytuacja w państwie pogłębia bezradność niektórych grup społecznych NKJPp. W języku słoweńskim operatory prymarnie denotujące 
zmniejszenie wysokości również służą jako składowe analityzmów, kauzatywów odpowiadających za mniejszą intensywność danej cechy, por. znižati - zniževati Gostoto stanovanjske gradnje so pomembno znižali NBp; S hrano znižujemo nevarnost rakavih obolenj NBp. Gradacja cechy, kauzowanie jej w stopniu wyższym niż równy, eksplikowane jest przez czasowniki operatorowe z pola transferu pol. dodać - dodawać - słoweń. dodati - dodajati - Dodali so mehkobo lasem. Zwiększnie lub zmniejszanie intensywności cechy może być też sygnalizowane przez werbalizatory z semantycznego pola siły i słabości, por. pol. wzmocnić wzmacniać lub osłabić - osłabiać - Tabletki wzmacniaja odporność skóry na promieniowanie TSp; Działania szpiegów ostabiaja efektywność działań dyplomatycznych NKJPp; Przewlekłe procedury osłabiają skuteczność narzędzi podatkowych NKJPp. Cechę o osłabionej intensywności można implikować używając polskiego czasownika operatorowego redukować - Przeszkody prawne redukują efektywność systemu NKJPp. Zmniejszanie intensywności cechy traktowanej jako niepożądana, a zarazem występująca w sposób intensywny, gwałtowny, może być zaznaczanie $\mathrm{w}$ analityzmach przez czasowniki pol. złagodzić - łagodzić - Płukanie łagodzi szorstkość dzianiny NKJPp; słoweń. oblažiti - blažiti - Padavine blažijo suhost. Zmniejszenie intensywności cechy, raczej niepożądanej, można zaznaczyć przez użycie czasowników przełamać-przełamywać - Surowość tapicerki przełamuja brelokami NKJPp; Pogodne barwy zasłon przełamują surowość wnętrza CZKp.

Czasowniki kauzatywne z kręgu wartości służą także jako werbalizatory $\mathrm{w}$ analityzmach określających zmianę intensywności implikowanej cechy. Jako podstawowe czasowniki związane z kręgu wartości funkcjonują pol. poprawić - poprawiać - Zabieg poprawił gładkość skóry NKJPp; Masło do ciała poprawi miękkość naskórka TSp; Krem poprawia elastyczność skóry. Ten czynnik poprawia krzepliwość krwi NKJPp; polepszyć - polepszać - Terapia polepsza sprężystość skóry NKJPp oraz pogorszyć pogarszać - Lokalizacja danych pogarsza efektywność programów NKJPp; Zakręty pogarszają ekonomiczność przejazdu NKJPp; upośledzić - upośledzać - Zanieczyszczenie środowiska upośledza sprawność oddechowa u pacjentów NKJPp. Czasowniki operatorowe wartościujące są reprezentowane w języku słoweńskim m. in. przez causativum izboljševati - Terapija izboljšuje mineralno gostoto kosti NPp.

W semantyce werbalizatorów obserwujemy kompilację różnych parametrów semantycznych, jak połączenie znaczenia terminatywnego, wzmocnionej intensywności wraz z określeniem gwałtowności i z punktu widzenia pacjensa niepożądanym, np. pol. naruszyć-naruszać - Bandyta naruszył doskonałość systemu komputerowego NKJPp; niszczyć-zniszczyć - słoweń. uničiti-uničevati - Dež je uničil lepoto mesta. 
Podobne znaczenia konotują polskie verba wypierać i wymazać, np. Wymazali polskość, węgierskość - gina całe kultury NKJPp; Niemcy wypierali polskość NKJPp.

Komponent przymusu występuję także w przypadku werbalizatorów pol. narzucić - narzucać - Rzeczywistość narzuca banalność NKJPp; wymusić - wymuszać - Kontrola wymusza efektywność NKJPp. Semantyka nadania niepożądanej cechy uwidacznia także kolokacja z werbalizatorem skazać - Bogaci skazali resztę na powściagliwość NKJPp. Cechy korzystne są w związkach przyczynowych wprowadzane m. in. przy użyciu pol. czasowników zapewnić - zapewniać - Zmniejszenie zespołu kierowniczego zapewni sprawność w podejmowaniu decyzji NKJPp; Antena zapewnia wymaganą częstość obrazów NKJPp. Przeciwdziałanie cechom niepożądanym jest sygnalizowane przez polskie verba zapobiec - zapobiegać - Zabieg w salonie fryzjerskim zapobiega nadmiernej puszystości włosów.

Warto zaznaczyć, że pewne zastrzeżenie jest wkomponowane w znaczenie czasownika przyczyniać się do występującego m.in. w konstrukcji Klimatyzacja przyczynia się do suchości pomieszczeń. Zdanie Klimatyzacja powoduje suchość pomieszczeń (por. słoweń. Klimatska naprava povzroča suhost prostorov) presuponuje pełną odpowiedzialność faktu zainstalowania i istnienia urządzeń klimatyzacyjnych za stan bycia suchym, podczas gdy zdanie z czasownikiem przyczynia się do zawiera komponent przyczyny towarzyszącej. Podobnie mniej kategoryczne w zakresie podawania przyczyny są czasowniki i zwroty wplywać oraz mieć wplyw, np. Podawanie tabletek z zielonej herbaty wplywa na krzepliwość krwi NKJPp; Wapń ma wplyw na krzepliwość krwi NKJPp; Zainstalowanie klimatyzacji ma wpływ na suchość pomieszczeń, por. słoweń. Klimatska naprava vpliva na suhost prostorov.

Przedmiotem obserwacji w niniejszym opracowaniu są różne konstrukcje przyczynowe ukazywane na materiale polskim i słoweńskim. Nie ograniczono się do tych analityzmów werbo-nominalnych, które uniemożliwiają transformację danego związku wyrazowego w zdanie złożone, por. Jego postępowanie rodzi smutek matki - ${ }^{*}$ Jego postępowanie rodzi to, że matka jest smutna, podczas gdy możliwa jest parafraza wyjściowego zdania we frazę To, jak on postępuje, powoduje (to), że matka jest smutna / smuci się. Również konstrukcje służące do parafrazowania badanych zdań włączono do analizy. Jednakże część z analizowanych połączeń wnosi własne odrębne, czasem peryfrastyczne znaczenie, które zgodnie z naturą metafory nie jest prostą sumą znaczeń składowych, ale charakteryzuje się swoistym znaczeniem globalnym.

Materiał poświadcza, że podstawę treści predykatywnej tworzą jednostki powiązane semantycznie i słowotwórczo z przymiotnikami określanymi w literaturze jako jakościowe, niewiele przymiotników relacyjnych leży u podstaw 
prezentowanych połączeń wyrazowych, dość dużo jest natomiast przymiotników predyspozycyjnych, nieobecne są przymiotniki dzierżawcze.

Czasowniki operatorowe, czyli werbalizatory, są w analizowanych związkach nośnikami przyczynowości, a jednocześnie transmitują właściwości jednostek werbalnych do danego analitycznego związku wyrazowego. Konstrukcje analityczne eksplicytnie ujawniają cechy semantyczne, które w jednostkach werbalnych kodowane są m.in. w postaci morfemów słowotwórczych. Konstrukcje analityczne wykazują większe możliwości niż kauzatywa o charakterze pojedynczych czasowników w zakresie modyfikacji treści. Parametry semantyczne są w analityzmach ujawnione eksplicytnie dzięki wydzieleniu części czasownikowej - werbalizatora charakteryzującego się autonomicznych znaczeniem, gdy występuje on poza strukturą analityczną.

Wiele z czasowników operatorowych $\mathrm{w}$ analitycznych konstrukcjach kauzatywnych parafrazowanych przez przymiotniki jest kauzatywami, czyli realizuje bazowy predykat kauzatywny. W ten sposób ujawniane powierzchniowo realizacje w postaci analitycznej cechuje wzmocniona, „podwójna kauzatywność" i bardzo duża kondensacja treści w danej jednostce predykatywnej, a tym samym w całej frazie zdaniowej.

\section{Źródła}

CZK - „Cztery Kąty”. Autorka wykorzystała tytuły czasopisma z lat 2011-2014.

NB - Nova Beseda - korpus języka słoweńskiego. Pobrano 31 grudnia 2015 z http://bos. zrc-sazu.si/s_beseda.html

NKJP - Narodowy Korpus Języka Polskiego. Pobrano 31 grudnia 2015 z http://www.nkjp.pl TS - „Twój Styl”. Autorka wykorzystała tytuły czasopisma z lat 2008-2014.

SSKJ - Slovar slovenskega knjižnega jezika, 2000, elektronska izdaja. Inštitut za slovenski jezik Frana Ramovša in avtorji. Ljubljana: ZRC SAZU.

\section{Bibliografia}

Grzegorczykowa, R. (2003). Kształtowanie się czasownikowych wykładników przyczynowości w dziejach polszczyzny. W I. Bobrowski (Red.), Anabasis: prace ofiarowane prof. K. Pisarkowej (ss. 99-106). Kraków: Lexis.

Kiklewicz, A. \& Korytkowska, M. (Red.) (2010). Podstawowe struktury zdaniowe współczesnych języków słowiańskich: białoruski, bułgarski i polski. Olsztyn: Centrum Badań Europy Wschodniej UWM. 
Agnieszka Zatorska Z Z problematyki polskich i słoweńskich analityzmów kauzatywnych...

Korytkowska, M. (1992). Typy pozycji predykatowo-argumentowych. Gramatyka konfrontatywna bułgarsko-polska (T. 5, Cz. 1). Warszawa: Slawistyczny Ośrodek Wydawniczy.

Korytkowska, M. \& Maldżieva, V. (1999). O pewnych cechach predykatorów analitycznych w językach bułgarskim i polskim. Rozprawy Komisji Językowej ŁTN, 44, 31-43.

Linde-Usiekniewicz, J. (2000). Określenia wymiarów w języku polskim. Warszawa: Wydano Nakładem Wydziału Polonistyki Uniwersytetu Warszawskiego.

Mindak, J. (1983). Peryfrastyczne konstrukcje predykatywne z parafraza przymiotnikową: na materiale polskim, serbsko-chorwackim i macedońskim. Wrocław: Ossolineum.

Narodowy Korpus Języka Polskiego [NKJP]. (b.d.). Pobrano 31 grudnia 2015 z www.nkjp.pl

Nova Beseda - korpus języka słoweńskiego [NB]. (b.d.). Pobrano 31 grudnia 2015 z http://bos. zrc-sazu.si/s_beseda.html

Slovar slovenskega knjižnega jezika [SSKJ]. (2000). Ljubljana: ZRC SAZU.

Zatorska, A. (2010). Causative predicates in Polish and Slovenian: the project of description. W K. B. Fischer, G. Krumbholz, M. Lazar \& J. Rabiega-Wiśniewska (Red.), Beiträge der Europäischen Slavistischen Linguistik (POLYSLAV) 13 (ss. 291-296). München, Berlin: Verlag Otto Sagner. (Die Welt der Slaven, 40).

Zatorska, A. (2012). Intensywność w semantyce kauzatywów: na materiale polskim i słoweńskim. W E. Kislova, K. Knapik-Gawin, E. Kubicka, K. Szafraniec, M. Tomancová \& S. Ulrich (Red.), Beiträge der Europäischen Slavistischen Linguistik (POLYSLAV) 15 (ss. 303-309). München, Berlin, Washington D. C.: Verlag Otto Sagner. (Die Welt der Slaven, 46).

Zatorska, A. (2013). Polskie i słoweńskie predykatory kauzatywne z parafraza przymiotnikową. Łódź: Wydawnictwo Uniwersytetu Łódzkiego.

Żmigrodzki, P. (2000). Właściwości składniowe analitycznych konstrukcji werbo-nominalnych w języku polskim. Katowice: Wydawnictwo Uniwersytetu Śląskiego.

\section{Some remarks on Polish and Slovene analytic causatives paraphrased by adjectives}

\section{Summary}

The article is devoted to the analytic causative predicates. The data is collected from Polish and Slovene. The basic methodological device is a paraphrase which obligatorily includes an adjective. Special attention is paid to operator verbs, which often have their own semantic features. Some of them are verbs of transfer, others - verbs of motion. In most cases, however, they are causatives 
which denote change of features. Apart from the basic causative category, the material is classified according to the its semantic features, including especially inchoativeness, terminativeness and restorativeness. In conclusion it is emphasized that analytic causatives show their semantic parameters more explicitly than is the case with verbal units and that they demonstrate considerable semantic condensity.

\section{Z problematyki polskich i słoweńskich analityzmów kauzatywnych z parafrazą przymiotnikową}

\section{Streszczenie}

Artykuł dotyczy analitycznych realizacji predykatu kauzatywnego. Materiał obejmuje przykłady z języków polskiego i słoweńskiego. Podstawowym narzędziem badawczym jest parafraza, która obligatoryjnie zawiera przymiotnik. Szczególną uwagę zwrócono na czasowniki operatorowe, które często mają samodzielne znaczenie. Niektóre z nich są czasownikami transferu, inne - czasownikami ruchu. Jednakże wiele $\mathrm{z}$ nich to także kauzatywa, określające zmianę cechy. Oprócz nadrzędnej kategorii kauzatywnej badane kauzatywa zostały poklasyfikowane ze względu na kategorię inchoatywności, terminatywności, restauratywności. We wnioskach podkreślono, że konstrukcje analityczne bardziej eksplicytnie niż jednostki werbalne ujawniają w swej budowie parametry semantyczne, jak również to, że charakterystyczna jest dla nich duża kondensacja semantyczna.

Keywords: Polish; Slovene; causatives; analytic predicate; semantics

Słowa kluczowe: język polski; język słoweński; predykaty kauzatywne; analityzmy; semantyka

Agnieszka Zatorska, University of Łódź

Correspondence: Agnieszka.Zatorska@uni.lodz.pl

This work was supported by a core funding for statutory activities from the Polish Ministry of Science and Higher Education.

Competing interests: the author declares that she has no competing interests. 